\title{
Response of soil microbiota to nine-year application of swine manure and urea
}

\author{
Resposta da microbiota do solo a nove anos de aplicações de dejetos suínos e ureia
}

\author{
Diana Morales $^{{ }^{\mathrm{I}}}$ Mónica Machado Vargas $^{\mathrm{I}}$ Michele Pottes de Oliveira ${ }^{\mathrm{I}}$ \\ Bruna Lunarde Taffe ${ }^{\mathrm{I}}$ Jucinei Comin ${ }^{\mathrm{I}}$ Claudio Roberto Soares ${ }^{\mathrm{II}}$ Paulo Lovato
}

\section{ABSTRACT}

Manure fertilization is a common practice, but little is known about its impacts on soil microbial activity and organic matter. Aiming to evaluate soil microbial response to nine years of successive applications of swine manure, organic carbon (TOC), total nitrogen (TN), pH, microbial biomass carbon $(M B C)$, basal respiration $(B R)$, metabolic quotient $(q C O)$, and enzyme ( $\beta$-glucosidase, phosphatase, arylsulphatase, and FDA) activities were measured in the $0-10 \mathrm{~cm}$ soil layer, in a no-tillage system. Treatments were: control soil without fertilization $(C)$, and application of two doses (104 and 209kg of $N \mathrm{ha}^{-1}$ year ${ }^{-1}$ ) of urea $\left(U_{1}\right.$ and $\left.U_{2}\right)$, pig slurry $\left(P S_{1}\right.$ and $\left.P S_{2}\right)$ and deep litter $\left(D L_{1}\right.$ and $D L_{2}$ ). TOC, TN, soil $p H, M B C$, and BR increased in soil fertilized with $D L$, and were lower in $U$ treatments. Soils with $U$ and $D L$ application had higher $q \mathrm{CO}_{2}$, related to different sources of stressors like nutrient imbalance. Phosphatase and $\beta$-glucosidase activities were not affected by treatments, increased with time, and had a strong correlation with $M B C$. We conclude that long-term swine manure applications increase microbial activity and soil organic matter, mainly in DL form; while urea applications have negative impacts on these indicators.

Key words: soil microbial activity, nitrogen amendments, soil quality.

\section{RESUMO}

A fertilização com dejetos suínos é uma prática comum, porém, pouco se conhece acerca de seus impactos sobre a atividade microbiana do solo e a matéria orgânica. Com o objetivo de avaliar a resposta da microbiota do solo, após nove anos de aplicações sucessivas de dejetos suínos, foram mensurados o carbono orgânico total (TOC), nitrogênio total (TN), pH, carbono da biomassa microbiana (MBC), respiração basal (BR), quociente metabólico $\left(q \mathrm{CO}_{2}\right)$ e a atividade enzimática ( $\beta$-glucosidase, fosfatase, arilsulfatase, e FDA), avaliações feitas na camada de 0 a $10 \mathrm{~cm}$ de profundidade em um solo sob plantio direto. Os tratamentos foram: solo controle sem fertilização $(C)$ e aplicação de duas doses $\left(104\right.$ e $209 \mathrm{~kg}$ de $\mathrm{N} \mathrm{ha}^{-1}$ ano $\left.^{-1}\right)$ de ureia $\left(U_{1}\right.$ e $\left.U_{2}\right)$, dejeto líquido $\left(P S_{1}\right.$ e $P S_{2}$ ) e cama sobreposta $\left(D L_{1}\right.$ e DL 2 ). O TOC, TN, o $\mathrm{pH}$ do solo, $M B C$ e BR incrementaram no solo fertilizado com $D L$ e foram mais baixos nos tratamentos com $U$. Os solos com aplicação de $U$ e DL apresentaram o maior $q \mathrm{CO}_{2}$, relacionado a diferentes fontes de estresse, como o desbalanço de nutrientes. A atividade da fosfatase e da $\beta$-glucosidase não foi afetada pelos tratamentos, mas incrementou com o tempo e teve uma forte correlação positiva com o MBC. Conclui-se que as aplicações de dejetos suínos em longo prazo incrementaram a atividade microbiana do solo e o teor de matéria orgânica, principalmente quando aplicados na forma de $D L$, enquanto que as aplicações de $U$ apresentaram impactos negativos sobre esses indicadores.

Palavras-chave: atividade microbiana do solo, adubos nitrogenados, qualidade do solo.

\section{INTRODUCTION}

Confined pork production generates large amounts of manure in small areas, and waste matter is stored and commonly used for crop fertilization. Use of swine manure as a fertilizer promotes nutrient recycling and improves soil structure and fertility, but mismanagement may result in environmental contamination because agricultural areas for disposal are limited. Thus, repeated applications may result in nutrient leaching, producing water contamination, and promoting algal blooms and eutrophication in surface water (ZHANG et al., 2012).

\footnotetext{
'Departamento de Engenharia Rural, Centro de Ciências Agrarias (CCA), Universidade Federal de Santa Catarina (UFSC), 88040-900, Florianópolis, SC, Brasil. E-mail: dianamarmol@gmail.com. "Corresponding author.

IDepartamento de Microbiologia, Imunologia e Parasitologia (MIP), Centro de Ciências Biológicas (CCB), UFSC, Florianópolis, SC, Brasil.
} 
Attributes of soil microbial community reflect effects of agricultural practices, like fertilization, because they respond quickly to changes in the environment, regulating organic matter decomposition and nutrient transformations. The most common biological soil quality indicators are: soil microbial biomass, basal respiration and metabolic quotient, the ratio between the former two parameters. Enzymatic activity is also commonly used to estimate activities related to specific nutrient cycles (GIACOMETTI et al., 2013).

Soil microbial biomass, consisting mainly of fungi and bacteria, is responsible for almost all-biological transformation in the soil. Since changes in microbial biomass are observed on a daily scale, while changes in soil organic matter may take decades, microbial biomass is used to assess the impact of different sources of stress on microorganisms. However, it must be evaluated along with others variables to assess soil biological processes (ANDERSON \& DOMSCH, 2010).

Basal respiration is an indicator of biological activity, especially catabolic processes of aerobic microorganisms related to organic matter decomposition, and to nutrient release or immobilization in the soil. Higher basal respiration can indicates enhanced microbial activity, but it can also indicate loss of soil organic matter especially in situations where $\mathrm{C}$ input is smaller than $\mathrm{C}$ output (ANDERSON \& DOMSCH, 2010). The ratio of basal respiration to microbial biomass, metabolic quotient $\left(q \mathrm{CO}_{2}\right)$, is used to evaluate microbial efficiency for substrate conversion in cell mass. High $q \mathrm{CO}_{2}$ values mean low growth efficiency, since $\mathrm{C}$ lost as $\mathrm{CO}_{2}$ is not used in new cellular tissue formation, also can mean stress due to biotic or abiotic factors and management conditions (WARDLE \& GHANI, 1995). Soil enzymes, synthesized mainly by microorganisms, have an important role in nutrient cycle, and their activities are responsive to changes in soil and plant management, such as residue or fertilizer application, as well as to crop rotation (GIACOMETTI et al., 2013).

Comparisons between organic and mineral fertilizers have shown that microbial communities respond differently to distinct nutrient sources. Soil biomass, $\mathrm{CO}_{2}$ evolution and enzymatic activity have shown increases above $30 \%$ in areas fertilized with swine manure in temperate regions (e.g., PLAZA et al., 2007; GIACOMETTI et al., 2013). On the other hand, mineral fertilizer application results in lower microbial biomass (above $20 \%$ ), $\mathrm{C} / \mathrm{N}$ ratio and enzyme activity, mainly $B$-glucosidase and phosphatase (MARSCHNER et al., 2003; GIACOMETTI et al., 2013). Furthermore, there is abundant literature describing pig slurry effects, but fewer studies have focused on swine manure in solid form (as deep litter) and compared to urea applications.

Thus, the present research aimed to evaluate changes in the response of soil microorganisms after nine years of repeated application of different kind of fertilizer, in a sandy Typic Hapludalf soil under no-tillage management. Particularly, we aimed to compare swine manure fertilization, in liquid (PS) and solid (DL) forms, as well as urea, evaluating how those fertilizers affected biological indicators of soil quality.

\section{MATERIAL AND METHODS}

The research was performed in a pork production farm in Southern Brazil (28 $8^{\circ} 14^{\prime} 20.7^{\prime \prime} \mathrm{S}$ and $49^{\circ} 13^{\prime} 55.5^{\prime \prime} \mathrm{W}, 300 \mathrm{~m}$ elevation) with Cfa humid subtropical climate and a sandy Typic Hapludalf soil (SOIL SURVEY STAFF, 2014). Before the establishment of the experiment (2002), physical and chemical attributes in 0-10 cm layer were measured: sand $330 \mathrm{~g} \mathrm{~kg}^{-1}$; organic matter $33 \mathrm{~g} \mathrm{~kg}^{-1}$; $\mathrm{pH}$ (water) 5.1; $\mathrm{pH}$ (SMP solution) 5.5; Mehlich-1 extractable $\mathrm{P}$

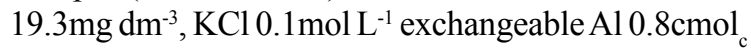
$\mathrm{kg}^{-1}, \mathrm{KCl} 0.1 \mathrm{~mol} \mathrm{~L}^{-1}$ exchangeable $\mathrm{Ca} 3.1 \mathrm{cmol}_{\mathrm{c}} \mathrm{kg}^{-1}$; $\mathrm{KCl} 0.1 \mathrm{~mol} \mathrm{~L}^{-1}$ exchangeable $\mathrm{Mg} 0.8 \mathrm{cmol}_{\mathrm{c}} \mathrm{kg}^{-1}$.

The experimental plots were established in 2002 with the following treatments: control without fertilization (C); two doses of annual pig slurry fertilization ( $\mathrm{PS}_{1}$ and $\mathrm{PS}_{2}$ ), deep-litter fertilization $\left(\mathrm{DL}_{1}\right.$ and $\left.\mathrm{DL}_{2}\right)$ and urea fertilization $\left(\mathrm{U}_{1}\right.$ and $\left.\mathrm{U}_{2}\right)$. The doses were an average of 104 and $209 \mathrm{~kg} \mathrm{~N} \mathrm{ha}^{-1} \mathrm{year}^{-1}$ respectively, taking in account the total $\mathrm{N}$ content of each fertilizer. The experimental design was in completely randomized blocks with three replications, and each plot was $27 \mathrm{~m}^{2}(4.5 \times 6.0 \mathrm{~m})$. PS was a mixture of swine excreta, cleaning water and feed remains; DL contained wood shavings, scraps and partially decomposed pig manure. The organic fertilizers and U were applied annually on the soil surface, without incorporation into the ground (Figure 1).

Soil samples were collected every 60 days from October 2010 to October 2011. Each soil sample consisted of 15 subsamples taken randomly from the $0-10 \mathrm{~cm}$ layer with an auger. After, soil samples were packed and transported in containers with ice. Part of the soil was air dried and set aside for chemical analyses; the other part was stored at $4^{\circ} \mathrm{C}$ until the microbiological assays were performed. Total nitrogen (TN) was evaluated by the Kjeldahl method, total organic carbon (TOC) by the Walkley-Black method, and $\mathrm{pH}$ in water, as described in TEDESCO 


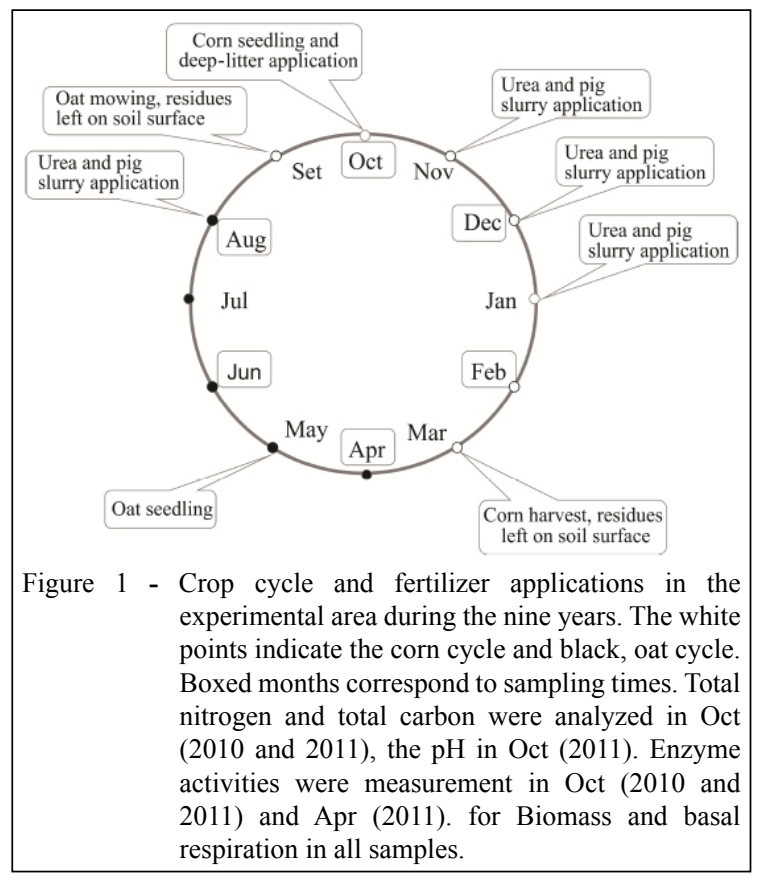

et al. (1995). Microbial biomass carbon (MBC) was determined by fumigation - extraction method, and prior to measurements the soil was incubated at room temperature and at moisture equivalent to $60 \%$ of total pore volume. Basal respiration (BR) was measured using the closed jar method. The air-tight jars contained $20 \mathrm{~g}$ of soil and were incubated for six days, at room temperature and darkness. Then, one beaker with $20 \mathrm{~mL}$ of $\mathrm{NaOH} 0.2 \mathrm{~mol} \mathrm{~L}^{-1}$ was placed in each jar. and subsequently, remaining $\mathrm{NaOH}$ was determined by titration with $\mathrm{HCl} 0.2 \mathrm{~mol} \mathrm{~L}^{-1}$. Metabolic quotient $\left(q \mathrm{CO}_{2}\right)$ was calculated as the ratio between basal respiration and microbial biomass (C$\mathrm{CO}_{2} / \mathrm{MBC}$ ). Activities of the enzymes $\beta$-glucosidase, acid phosphatase, arylsulphatase and hydrolysis of fluorescein diacetate (FDA) were measured using colorimetric methods. All of these methods were made following the described by ALEF \& NANNIPIERI (1995). Sampling dates are shown in figure 1.

Data were submitted to analysis of variance as split-plots, with harvest times as main plots and fertilization treatments as sub-plots, and $q \mathrm{CO}_{2}$ data were transformed to square roots. Means were separated using the Scott-Knott test with $\mathrm{P} \leq 0.05$. Pearson correlations were calculated for the variables. Average TOC for each fertilization treatment was compared with the value measured at the beginning of the experiment (2002) using the Student t test. All analyses were performed using the SISVAR software (FERREIRA, 2000).

\section{RESULTS AND DISCUSSION}

Soil $\mathrm{pH}$ was lower in the $\mathrm{U}$ and $\mathrm{PS}_{2}$ areas, as compared to other treatments (Table 1). Soil $\mathrm{pH}$ decreased with successive application of fertilizers, a process enhanced in soils receiving urea or materials containing urine, such as PS, due to the protons release during the oxidation of $\mathrm{N}$; on the other hand, higher carbonate content in DL promotes consumption of $\mathrm{H}^{+}$dissolved in the soil, leading to $\mathrm{pH}$ increases (BRUNETTO et al., 2012). In this study, $\mathrm{pH}$ of DL treatment was similar to the control soil, with values around 6.0. Lower $\mathrm{pH}$ in the $\mathrm{U}$ and $\mathrm{PS}_{2}$ treatments may decrease P uptake by plants (MEURER, 2007).

Areas receiving DL had increases of soil TOC and TN (up to 58 e 70\%, respectively), in relation to control treatment (Table 1). PS and U showed lower contributions on the soil TOC and TN content. DL has higher contents of organic matter and recalcitrant carbon compounds with low mineralization rates (GIACOMINI et al., 2008) that may be responsible for increases in TOC and TN. The low mineralization rate of DL may have also caused the increase in TOC over the nine years, as compared to the baseline in $2002\left(33 \mathrm{~g} \mathrm{~kg}^{-1}\right.$ soil), with TOC increases of 60,30 and $10 \%$ in soils receiving $\mathrm{DL}_{2}, \mathrm{DL}_{1}$ and $\mathrm{PS}_{2}$ respectively. TOC in control soil did not increase, in comparison to the baseline, despite crop straw additions. This indicates that straw input is not sufficient to promote soil organic matter increase, probably because it is rapidly mineralized by soil microorganisms. However, in fertilized plots, the gain in biomass could be higher and the addition of crop straw could also influence the increases in TOC, due to increses in plant dry matter and nutrient content (LOURENZI et al., 2014).

Table 1 - Total organic carbon (TOC), total nitrogen (TN) and $\mathrm{pH}$ in unfertilized soil (C) or fertilized with pig slurry ( $\mathrm{PS}_{1}$ and $\left.\mathrm{PS}_{2}\right)$, deep-litter $\left(\mathrm{DL}_{1}\right.$ and $\left.\mathrm{DL}_{2}\right)$ and urea $\left(\mathrm{U}_{1}\right.$ and $\left.\mathrm{U}_{2}\right)$ at 104 and $209 \mathrm{~kg} \mathrm{~N} \mathrm{ha}^{-1}$ year $^{-1}$.

\begin{tabular}{lccc}
\hline \multirow{2}{*}{ Treatments } & TOC & TN & pH \\
\hline $\mathrm{C}$ & $---1.7 \mathrm{c}$ & $0.94 \mathrm{~b}$ & $5.4 \mathrm{a}$ \\
$\mathrm{U}_{1}$ & $31.5 \mathrm{c}$ & $0.86 \mathrm{~b}$ & $4.8 \mathrm{~b}$ \\
$\mathrm{U}_{2}$ & $32.2 \mathrm{c}$ & $0.91 \mathrm{~b}$ & $4.8 \mathrm{~b}$ \\
$\mathrm{PS}_{1}$ & $33.1 \mathrm{c}$ & $1.00 \mathrm{~b}$ & $5.6 \mathrm{a}$ \\
$\mathrm{PS}_{2}$ & $36.2 \mathrm{c}$ & $1.20 \mathrm{~b}$ & $5.1 \mathrm{~b}$ \\
$\mathrm{DL}_{1}$ & $44.2 \mathrm{~b}$ & $1.60 \mathrm{a}$ & $5.7 \mathrm{a}$ \\
$\mathrm{DL}_{2}$ & $51.7 \mathrm{a}$ & $1.70 \mathrm{a}$ & $6.1 \mathrm{a}$ \\
\hline
\end{tabular}

Means followed by the same letter in each column do not differ significantly according to the Scott-Knott test at $5 \%$. 
Although the PS have a high concentration of N, this treatment did not increase the levels of this nutrient in the soil and this may be associated to its rapid immobilization in plants tissues and microorganisms, or to losses due to $\mathrm{N}$ volatilization $\left(\mathrm{N}_{2} \mathrm{O} ; \mathrm{NH}_{3}\right)$ or leaching $\left(\mathrm{NO}_{3}^{-}\right)$(PLAZA et al., 2007). These processes happen rapidly since most of the PS nitrogen is in the ammoniacal $\mathrm{N}$ form $\left(\mathrm{NH}_{3} ; \mathrm{NH}_{4}^{+}\right)$and was placed in the soil surface, factor that increases losses over ten times (GIACOMINI et al., 2013). The soil fertilized with $\mathrm{U}$ also exhibited $\mathrm{N}$ losses, which can be due to rapid volatilization of this fertilizer.

The MBC showed no differences among control soil, $\mathrm{DL}_{1}, \mathrm{PS}_{1}$ and $\mathrm{PS}_{2}$ (Figure 2a), but soils receiving $\mathrm{DL}_{2}$ showed a $43 \%$ increase, while in soils receiving $\mathrm{U}_{1}$ and $\mathrm{U}_{2}$ MBC decreased by $13 \%$ and $32 \%$, respectively, as compared to the control. PLAZA et al. (2007) showed that, MBC of soils PS-fertilized showed higher values (increments ranging from 30 to $50 \%$ ) for several days after application, with gradual decreases

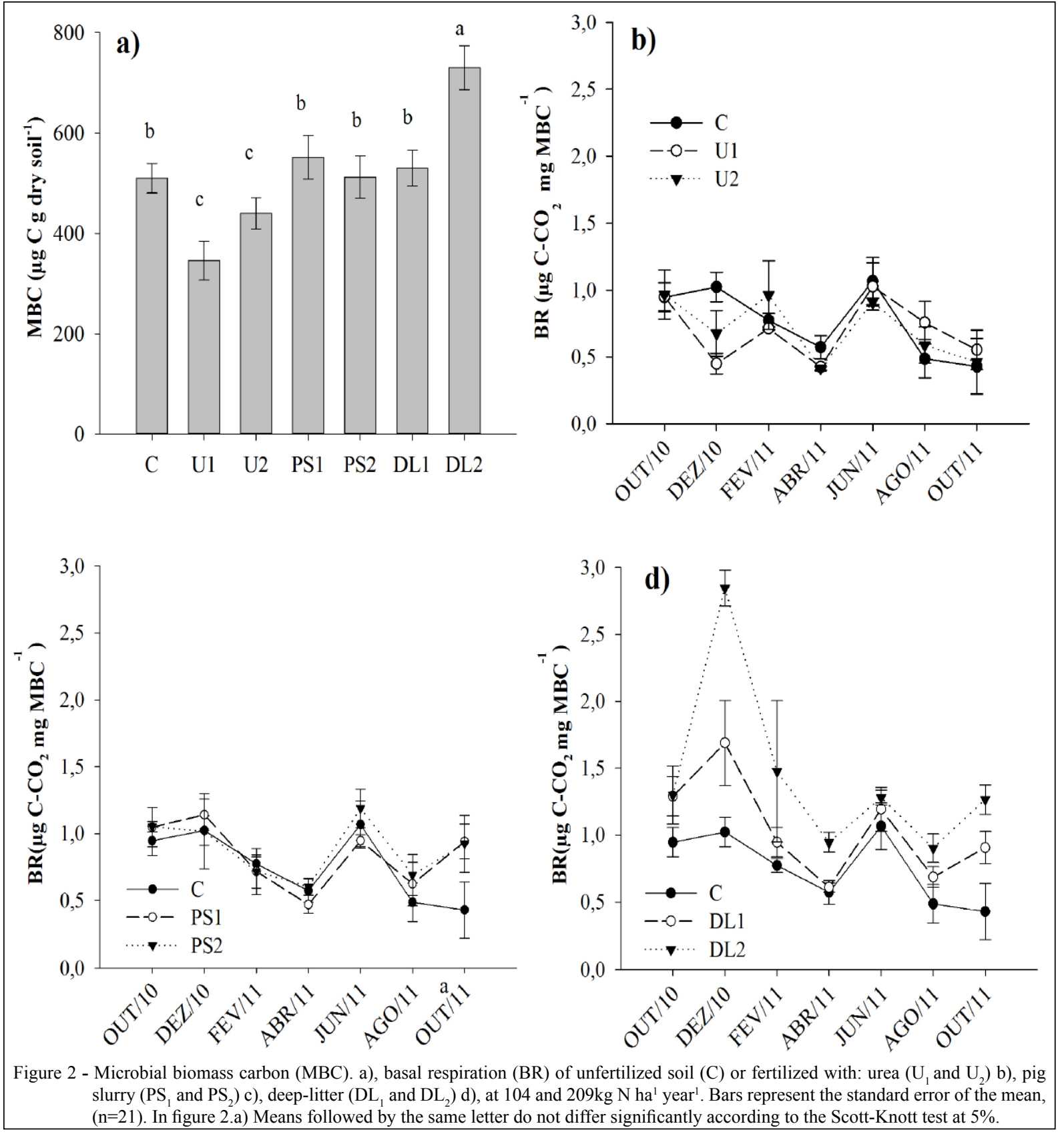

Ciência Rural, v.46, n.2, fev, 2016. 
towards values close to control treatments, in periods ranging from 45 to 60 days. In this paper, the first phase of biomass growth is linked to degradation of manure labile compounds suggesting that, successive additions of liquid manure temporarily stimulate soil microorganisms. In soil receiving $\mathrm{DL}_{2}, \mathrm{MBC}$ increase is probably due to its higher nutrient and organic carbon content. Substrates with high organic content promote a more dynamic ecological succession, since they are attacked by organisms capable of degrading high-molecular weight molecules, while less specialized organisms can grow on the partially degraded substrates (GESSNER et al., 2010). MBC decreases in soils fertilized with urea may be due to the lack of $\mathrm{C}$ and micronutrients, which limit microbial growth and reproduction (GIACOMETTI et al., 2013). Decreases in $\mathrm{MBC}$ in soils with applications of $U$ were associated with the adverse effects of drastic $\mathrm{pH}$ changes caused by this fertilizer (Table 1), as discussed above. According to a meta-analysis of MBC in soils from different biomes in Brazil, the values observed in this study are close to those reported for agricultural soils in the Atlantic Forest biome (491 to $591 \mu \mathrm{g} \mathrm{C}$ $\mathrm{g}^{-1}$ dry soil), except for the treatments with $\mathrm{U}$, which remained below the average values observed in the region (KASCHUK et al., 2010).

In general, soils receiving organic fertilizer had enhanced metabolic microbial activity, estimated as $\mathrm{CO}_{2}$ production (Figure $2 \mathrm{~b}$ and $2 \mathrm{c}$ ); with DL plots showing higher values than PS soils. The largest increases in soil microbial activity after application of pig manure occur in the first 30 days after manure application, and decrease to values similar to those in soils without addition of organic material (GIACOMINI et al., 2008). On the other hand, decreases in $\mathrm{CO}_{2}$ flow in U-amended soils (Figure 2d) can be explained by the lower carbon input associated to it. GIACOMETTI et al. (2013) showed that soils receiving only urea had lower $\mathrm{CO}_{2}$ production (reductions about 20\%) when compared to those receiving organic amendments. Furthermore, soil $\mathrm{pH}$ decrease as caused by urea fertilization in the present research, inhibits growth of several groups of organisms. Season was other important factor for BR responses. From April to September, the coldest season, there were no differences in BR among plots amended with PS, DL and U. Low temperatures may have limited soil microbial activity, since temperature and soil moisture are primary factors controlling seasonal variation of $\mathrm{CO}_{2}$ production (GIACOMETTI et al., 2013).

Soils amended with $\mathrm{PS}_{2}, \mathrm{DL}_{1}, \mathrm{DL}_{2}$ and $\mathrm{U}_{1}$ showed the greatest $q \mathrm{CO}_{2}$ values $(0.45$ to $0.52 \mathrm{mg}$
$\mathrm{C}-\mathrm{CO}_{2} \mathrm{mg}^{-1} \mathrm{MBC} \mathrm{h}^{-1}$ ), and these treatments were higher than $\mathrm{C}, \mathrm{PS}_{1}$ and $\mathrm{U}_{2}$ with values ranging from

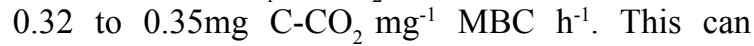
indicates stress in microbial communities, affected by changes in the community structure, substrate release or immobilization, and by soil management (WARDLE \& GHANI, 1995; GIACOMETTI et al., 2013). Higher values of $q \mathrm{CO}_{2}$ are found in microbial communities submitted to adverse conditions, in which microorganisms spend more energy (i.e., carbon compounds) for their maintenance in detriment of population growth (ANDERSON \& DOMSCH, 2010). In the case of U-amended soils, the stress may be related to acidic $\mathrm{pH}$ and/or urea's low $\mathrm{C} / \mathrm{N}$ ratio, causing microorganisms to enter a high level of competition for carbon. On the other hand, successive fertilizations with PS and DL create a situation in which there may be high competition for available nutrients and constant changes in the community composition, which is based on substratum availability.

The fertilization treatments had no effect on enzyme activity, and the values were: $\beta$-glucosidase: $217.2 \mu \mathrm{g}$ PNP $\mathrm{g}^{-1}$ dry soil $\mathrm{h}^{-1}$, phosphatase: $277.3 \mu \mathrm{g}$ PNP $\mathrm{g}^{-1}$ dry soil $\mathrm{h}^{-1}$, aryl-sulphatase: $317.8 \mu \mathrm{g}$ PNP $\mathrm{g}^{-1}$ dry soil $\mathrm{h}^{-1}$ and FDA hyrolysis: $85.9 \mathrm{mg}^{\mathrm{PNP}} \mathrm{g}^{-1}$ dry soil $\mathrm{h}^{-1}$. Some researches reported increases in activity of several enzymes in soils after a single application of swine manure (PLAZA et al., 2007; GIACOMETTI et al., 2013), but that may vary, for example, MARSCHNER et al. (2003) found no differences in enzymatic activity of soils with organic and mineral amendments in a long-term experiment and stated that enzyme activity measured may be masked, since the assays used indicate the potential activity, but not the actual enzyme activity in the soil.

There were changes in enzyme activity due to sampling time. In Oct. 2011 the activities of $\beta$-glucosidase, phosphatase, sulphatase, and FDA were $2.0 ; 3.8$ and 3.6 times higher, respectively, than in Oct. 2010. This result, and the high correlation between enzyme activities and microbial biomass $(\mathrm{r}=0.67, \quad \mathrm{P}<0.01)$, suggest that enzyme activity increase is caused by the growth of microbial populations or by a shift in the microbial communities foraging different substrates (GESSNER et al., 2010). The activity of $\beta$-glucosidase and acid phosphatase is within the levels reported for these enzymes in other no-tillage soil systems in Southern Brazil. However, arylsulphatase activity was at least 10 times greater than those previously assessed (BALOTA et al., 2011). High arylsulphatase activity levels indicate increases in fungus biomass, since 
this enzyme is related to ergosterol, a component of fungal cell membranes. No-tillage system can create favorable growth conditions for fungi, due to fewer disturbances. Thus, it is likely that the high activity of arylsulphatase recorded in this experiment is possibly associated with the soil management system adopted in the study area. Other studies in the same area have shown increases in soil carbon and significant changes in physical attributes due to application of swine manure (COMIN et al., 2013), associated with nutrients accumulation, such as phosphorus (GUARDINI et al., 2012). The present research has shown changes in soil microbial biomass and activity due to different forms of $\mathrm{N}$ fertilizers, which may impact soil quality as a whole.

\section{CONCLUSION}

Long term swine manure applications, in a no-tillage system, increase microbial activity and soil organic matter, while urea applications have negative impacts on these parameters. Swine manure amendments are useful for nutrient crop supply and integrated in a no-tillage system, significantly improve soil quality. Swine manure in deep litter form, is more efficient than slurry or urea in promotion of soil microbiota and carbon storage.

\section{ACKNOWLEDGMENTS}

The authors acknowledge the financial support from Coordenação de Aperfeiçoamento de Pessoal de Nível Superior(CAPES).

\section{REFERENCES}

ALEF, K.; NANNIPIERI, P. Methods in applied soil microbiology and biochemistry. London: San Diego: Academic, 1995. 576p.

ANDERSON, T.H.; DOMSCH, K.H. Soil microbial biomass: the eco-physiological approach. Soil Biology and Biochemistry, v.42, n.12, p.2039-2043, 2010. Available from: <http://linkinghub. elsevier.com/retrieve/pii/S0038071710002555>. Accessed: Jun. 07, 2012. doi: 10.1016/j.soilbio.2010.06.026.

BALOTA, E.L. et al. Soil enzyme activities under pig slurry addition and different tillage systems. Acta Scientiarum. Agronomy, v.33, n.4, p.729-737, 2011. Available from: <http://periodicos.uem.br/ ojs/index.php/ActaSciAgron/article/view/9816>. Accessed: May 04, 2012. doi: 10.4025/actasciagron.v33i4.9816.

BRUNETTO, G. et al. Changes in soil acidity and organic carbon in a sandy typic hapludalf after medium-term pig-slurry and deeplitter application. Revista Brasileira de Ciência do Solo, v.36, n.5, p.1620-1628, 2012. Available from: <http://www.scielo.br/
scielo.php?pid=S0100-06832012000500026\&script=sci_arttext $>$. Accessed: Mar. 17, 2014.

COMIN, J. et al. Physical properties and organic carbon content of a Typic Hapludult soil fertilised with pig slurry and pig litter in a no-tillage system. Soil Research, v.51, n.5, p.459, 2013. Available from: <http:/www.publish.csiro.au/?paper=SR13130>. Accessed: Apr. 21, 2014. doi: 10.1071/SR13130.

FERREIRA, D.F. Sisvar: a computer statistical analysis system. Ciência e Agrotecnologia, v.35, n.6, p.1039-1042, 2011. Available from: <http:// www.scielo.br/scielo.php?pid=S1413-70542011000600001\&script $=$ sci_ arttext\&tlng=pt>. Accessed: Oct. 3, 2010.

GESSNER, M. etal. Diversity meets decomposition. Trends in Ecology \& Evolution, v.25, n.6, p.372-380, 2010. Available from: <http:// www.sciencedirect.com/science/article/pii/S016953471000039X>. Accessed: Feb. 18, 2012. doi: 10.1016/j.tree.2010.01.010.

GIACOMETTI, C. et al. Chemical and microbiological soil quality indicators and their potential to differentiate fertilization regimes in temperate agroecosystems. Applied Soil Ecology, v.64, p.32-48, 2013. Available from: $<$ http://linkinghub.elsevier.com/retrieve/pii/ S0929139312002417>. Accessed: Feb. 19, 2015. doi: 10.1016/j. apsoil.2012.10.002.

GIACOMINI, S.J. et al. Mineralização do carbono da palha de aveia e dejetos de suínos aplicados na superfície ou incorporados ao solo. Revista Brasileira de Ciência do Solo, -v.32, p.26612668, 2008. Available from: <http://www.scielo.br/pdf/rbcs/ v32nspe/08.pdf>. Accessed: Jul. 16, 2012.

GIACOMINI, S.J. et al. Transformações do nitrogênio no solo após adição de dejeto líquido e cama sobreposta de suínos. Pesquisa Agropecuária Brasileira, v.48, n.2, p.211-219, 2013. Available from: $<$ http://www.scielo.br/scielo.php?script $=$ sci arttext\&pid=S0100-204X2013000200012\&lng=pt\&nrm=iso \&tlng=en>. Accessed: Nov. 23, 2012. doi: 10.1590/S0100204X2013000200012>

GUARDINI, R. et al. Accumulation of phosphorus fractions in typic Hapludalf soil after long-term application of pig slurry and deep pig litter in a no-tillage system. Nutrient Cycling in Agroecosystems, v.93, n.2, p.215-225, 2012. Available from: <http://link.springer. com/10.1007/s10705-012-9511-3>. Accessed: Mar. 15, 2014. doi: $10.1007 / \mathrm{s} 10705-012-9511-3$.

KASCHUK, G. et al. Three decades of soil microbial biomass studies in Brazilian ecosystems: lessons learned about soil quality and indications for improving sustainability. Soil Biology and Biochemistry, v.42, n.1, p.1-13, 2010. Available from: <http:// linkinghub.elsevier.com/retrieve/pii/S0038071709003095>. Accessed: Oct. 06, 2012. doi:10.1016/j.soilbio.2009.08.020.

LOURENZI, C.R. et al. Pig slurry and nutrient accumulationand dry matter and grain yield in various crops. Revista Brasileira de Ciência do Solo, v.38, p.949-958, 2014. Available from: <http:// www.scielo.br/pdf/rbcs/v38n3/27.pdf $>$. Accessed: Apr. 17, 2014.

MARSCHNER, P. et al. Structure and function of the soil microbial community in a long-term fertilizer experiment. Soil Biology and Biochemistry, v.35, n.3, p.453-461, 2003. Available from: <http:// www.sciencedirect.com/science/article/pii/S0038071702002973>. Accessed: Oct. 23, 2014. doi: 1.0.1016/S0038-0717(02)00297-3. 
MEURER, E.J. Fatores que influenciam o crescimento e o desenvolvimento das plantas. In: Fertilidade do solo. Viçosa MG: Sociedade Brasileira de Ciência do Solo, 2007. V.1, p.65-90.

PLAZA, C. et al. Microbial activity in pig slurry-amended soils under aerobic incubation. Biodegradation, v.18, n.2, p.159-165, 2007. Available from: $<$ http://link.springer.com/10.1007/s10532-006-90510>. Accessed: Oct. 04, 2012. doi: 10.1007/s10532-006-9051-0.

SOIL SURVEY STAFF. Keys to soil taxonomy. 12.ed. Washington, DC.: USDA-Natural Resources Conservation Service, 2014. 363p.
TEDESCO, M.J. et al. Análises de solo, plantas e outros materiais. Porto Alegre: UFRGS, 1995. 174p.

WARDLE, D.A.; GHANI, A. A critique of the microbial metabolic quotient $\left(q \mathrm{CO}_{2}\right)$ as a bioindicator of disturbance and ecosystem development. Soil Biology and Biochemistry, v.27, n.12, p.16011610,1995

ZHANG, Y. et al. Pig production in subtropical agriculture. Journal of the Science of Food and Agriculture, v.92, n.5, p.1016-1024, 2012. Available from: <http://doi.wiley.com/10.1002/jsfa.4679>. Accessed: Jul. 13, 2013. doi:10.1002/jsfa.4679. 